\title{
CEO Leadership Competency Profiling in Statutory Government Corporations in Sub-Saharan Africa: A Case in Uganda
}

\author{
Dickinson Dunstan Turinawe \\ Department of Management Science, Makerere University Business School, Kampala, Uganda \\ Email: dturinawe@mubs.ac.ug
}

How to cite this paper: Turinawe, D.D. (2021) CEO Leadership Competency Profiling in Statutory Government Corporations in Sub-Saharan Africa: A Case in Uganda. Open Access Library Journal, 8: e8205. https://doi.org/10.4236/oalib.1108205

Received: November 18, 2021

Accepted: December 27, 2021

Published: December 30, 2021

Copyright $\odot 2021$ by author(s) and Open Access Library Inc.

This work is licensed under the Creative Commons Attribution International License (CC BY 4.0).

http://creativecommons.org/licenses/by/4.0/ (c) (i) Open Access

\begin{abstract}
Purpose: To identify the critical leadership competency profile for CEOs of Ugandan Statutory Government Corporations (SGCs) in Uganda. In order to achieve this aim, the research set out to identify the characteristics of a leadership competency framework for CEOs of SGCs. Design/Methodology/Approach: This was a cross-sectional survey based on a population of 93 SGCs and a sample size of 60 in Uganda with a total of 300 respondents. Propositions were evaluated using independent samples t-tests and Exploratory Factor Analysis (EFA) to identify the differentiating and threshold CEO Leadership Competencies (CEO LCs). Findings: Both CEO differentiating and threshold leadership competencies were found to constitute leadership-oriented and management-oriented competencies leading to the conclusion that at the CEO level, the concept of managerial leadership competencies was the appropriate framework for effective CEOs of SGCs. The threshold managerial leadership competencies were clustered under three components-participative, team building, emotional intelligence and conscientiousness CEO LCs. The differentiating managerial leadership competencies were clustered under two main components-conceptual and administrative CEO LCs. Research Limitations/Implications: The research focused on SGCs that excluded Government administrative bodies such as Government departments, local Governments and Academic Institutions. It may, therefore, not be generalizable for all SGCs. It also challenged the argument regarding the difference between leadership and management. It supported the argument that at the CEO level, leadership and management were complementary, and an effective CEO needed to have both managerial and leadership competencies. Originality/Value: The study generated empirical evidence on the phenomenon of managerial leadership competencies for CEOs of SGCs in Uganda. It suggested that at the CEO level, managerial and leadership competencies were complementary for effective orga-
\end{abstract}


nizational performance.

\section{Subject Areas}

Sociology

\section{Keywords}

Leadership Competency, Statutory Government Corporations, Managerial Leadership Competencies, Upper Echelon Characteristics, Organizational Performance

\section{Introduction}

The purpose of this paper was to identify the leadership competency profile for CEOs of SGCs in Uganda. SGCs are autonomous or semi-autonomous entities, wholly- or partially-owned by governments that operate under a board of directors [1]. In Uganda, SGCs are important institutions charged with public service delivery [2]. They are formed to provide service delivery on behalf of the government, yet reports suggest that SGCs are not of much value to society [3].

Organizational reforms of SGCs in Uganda have not improved service delivery; instead, the public continues to detest service delivery of a number of SGCs [4]. [3] added that SGCs operate under financial deficits having less than stellar systems, overdue debts, redundant staff, and lack citizen expectations. In 2014, the auditor general noted poor performance of SGCs which he categorized in terms of unqualified audit opinion, qualified opinion, disclaimer of opinion, and adverse opinion. According to the report, an unqualified audit opinion is issued when the auditor is able to express an opinion and concludes that the financial statements of an audited entity provide a true and fair view in accordance with the stated financial reporting framework and the various acts and statutes establishing the SGCs. A qualified opinion means that the auditor is unable to obtain sufficient appropriate audit evidence on which to base the opinion, but the auditor concludes that the possible effects on the financial statements of undetected misstatements could be material but not pervasive. A disclaimer of opinion means that the auditor is unable to obtain sufficient appropriate audit evidence on which to base the opinion, and the auditor concludes that the possible effects on the financial statements of undetected misstatements are both material and pervasive. An adverse opinion is when the auditor, having obtained sufficient appropriate evidence, concludes that misstatements are both material and pervasive to the financial statements.

In the report, it was noted that out of the 108 accounts audited, 67 contained unqualified opinions, 39 included qualified opinions, and two contained disclaimer opinions. The report pointed out a financial audit query in the SGC sector amounting to $\$ 233$ million USD. In addition to the financial query, the report also highlighted leadership and management issues. These included governance 
issues such as lack of board charters, ineffective fraud control policies, inefficient internal audit functions, lack of succession planning, conflicts of interest, the improper constitution of audit committees and inefficient senior management. Additional management and leadership issues included lack of strategic development plans, disregard for procurement laws, high staff turnover, and staffing gaps; for example, of the approved positions, only $47 \%$ were filled.

Scholars and practitioners suggest that effective leadership behaviours can facilitate the improvement of performance when organizations face new challenges [5] [6]. This view is supported by [7] who argued that most studies that have examined the connection between leadership paradigms and behaviours and organizational performance have shown a positive relationship with organizational performance. Given the data that shows perennial poor performance of SGCs, the leadership competencies of CEOs of SGCs are of interest and this constituted the motivation for this research.

The paper covers introduction, literature review, methodology, results and discussions and ends up with conclusions and implications.

\section{Literature Review and Proposition Development}

\subsection{Performance of Organizations}

Many authors have different definitions of performance [8]. Organizational Performance (OP) is the most important criterion in evaluating organizations, their actions, and environments [9]. The definition of $\mathrm{OP}$ is a surprisingly open question with few studies using consistent definitions and measures [10]. In order to define OP, there is a need to look at a closely related construct of organizational effectiveness subsequently known as OP [11] [12]. It encompasses three specific areas of firm outcomes: financial performance (profits, return on assets, return on investment, etc.), market performance (sales, market share, etc.) and shareholder return (total shareholder return, economic value added). On the other hand, organizational effectiveness is broader and captures OP plus the plethora of internal performance outcomes normally associated with more efficient or effective operations. It also includes other external measures that relate to considerations that are broader than those simply associated with economic valuation such as reputation [9].

When using the organizational model, determining the appropriate construct of performance or effectiveness, involves measures ranging from employee satisfaction to shareholder wealth [13] [14] [15]. [16] posited that managers can influence the behavior of their employees (and thus the performance of the organization) by taking into account factors such as the formal and informal structure, the planning, reward, control and information systems, their skills and personalities and the relation of these to the environment. It is further argued that actions of managers influence organizational outcomes by establishing context that constitutes a complex set of psychological, sociological and physical interactions. 
The definition of OP is, surprisingly, an open question with few studies using consistent definitions and measures [10]. Organization performance of SGCs was conceptualized using the concepts of organizational effectiveness and the organizational model of the firm. The nature of services rendered by SGCs means that their OP is broad and can be considered to include aspects of organizational effectiveness, such as perceived service delivery and employee satisfaction. In Uganda, SGCs are important institutions charged with public service delivery [2]. The Auditor General's report was used as the reference for the categorization of SGCs. This was considered appropriate because the functions of the Auditor General, as spelt out in the National Audit Act, 2008, are to give opinion on the service delivery performance of SGCs based on the financial reports on their operations.

\subsection{Research Proposition}

In this study, research propositions were used instead of research hypotheses because the empirical part of the study was exploratory in nature and the research was not based on previous models [17].

\subsubsection{Managerial Leadership Competencies \\ Proposition 1}

There is a continuing controversy about the difference between leaders and managers [18]. Some scholars argue that although leadership and management overlap, the two are not synonymous and the overlap is a point of disagreement [19] [20] and there even extreme debates which posit that a good leader cannot be a good manager [21]. Despite these arguments, [22] contends that in today's dynamic environment, organizations need both leaders and managers. Given these controversial arguments, at CEO level, the difference between management and leadership competencies is blurred and CEO impact on Organizational performance may be predicted by a mix of the two sets of competencies.

[23] observed that organizations needed both leaders and managers in order to reach their goals although he argued that managers had different contributions. [24] [25] posited that leaders do right things while managers do things right. Moreover, for organizations to survive in the twenty-first century, they need new generation of leaders [26]. [27] argued that leadership goes beyond routine tasks to cope with change while management is a regular formal responsibility to cope with routine tasks. Leadership focuses on the vision of the organization and inspires the members of the organization for the realization of that vision. In contrast management aims at controlling the organization's formal functions [28]. Although [29] contends that the two are not synonymous, he observes that the two are complementary.

[18] [30] observe that the primary mission of leaders and managers is to control and influence other people and that the most important difference is the approach to achieve the goals. He argues that balancing the role of both management and leadership are critical to the organizations success. On this account, it 
can be argued that at the level of a CEO, leadership and management are complementary. The CEO is the accounting officer of SGC and has to take all manner of decisions that have far reaching implication for the organization. This means that the competency profile that underlies effective and efficient decisions and actions needs to be multi-dimensional. This brings in the concept of managerial leadership which integrates both management and leadership to identify the critical CEO leadership competencies for SGC in Uganda. From the above debate the following proposition was developed:

P1. There is agreement amongst respondents on the need for managerial and leadership competencies at CEO level.

\subsubsection{CEO Management and Leadership Competency Clusters}

\section{Proposition 2, 3, 4 and 5}

A review of literature on research by [21] [31]-[39], GLOBE 2013 project by [40] [41] [42] [43] revealed an integrated sets of MLCs in terms of manager behaviours and attributes which can be directed towards successful goal achievement within one's job, to agreed work standards, and that can be improved via training and development.

The above analysis formed the basis for integrated CEO leadership competency framework based on the review of competency models in extant literature, the works of [44] and the leadership behaviors identified by [40] [45] as a result of GLOBE 2013 project. For the purpose of this study CEO managerial leadership competencies as defined by [37] [39], were adopted to mean the ability to integrate opposite and complex roles in order to manage human relation functions, organize, adapt and be productive, in pursuit of the organization's goals. From the above narrative the following propositions were developed:

P2. There is a cluster of CEO Threshold Managerial Leadership Competencies.

P3. There is a cluster of differentiating Managerial Leadership Competencies.

P4. The differentiating managerial leadership competencies can be categorized into principle components.

P5. The threshold managerial leadership competencies can be categorized into principle components.

\section{Methodology}

The study applied a quantitative research design using survey questionnaires. The instrument to measure CEO Leadership competencies was developed from a review of managerial and leadership competency models. Organizational performance was measured on the basis of organizational model of the firm using Auditor General's Opinion on the performance of SGC.

\subsection{CEO Managerial Leadership Competency Instrument}

This contemplated research focused on the complementary nature of the phi- 
losophy of management and leadership and the two constituted the basis for the leadership competencies for a CEO of a SGC in Uganda. An instrument consisting of 143 items was developed from the models in extant literature under categories outlined in Table 1 below:

For purposes of this research the instrument constituted an integrated framework consisting Managerial and leadership competencies was adopted for measuring the CEO Managerial Leadership competencies.

The questionnaire developed from the review of leadership competency models in extant literature consisted of two sections. Section A covering demographic questions regarding age, sex, education, length of service, and organization while Section B covered the self-administered questionnaire for measuring CEO LCs, using a 5-point Likert scale ranging from strongly disagree, disagree, not sure, agree, or strongly agree. Negative questions that are reverse coded were also used. These are summated rating scales that consisted of statements that express either a favourable or an unfavourable attitude toward the object of interest [46].

\subsection{SGC Organizational Performance Measurement}

The auditor general opinion categorizes performance of SGCs, in terms unqualified audit opinion, qualified opinion, disclaimer of opinion, and adverse opinion. An unqualified audit opinion is issued when the auditor is able to express an opinion and concludes that the financial statements of an audited entity provide a true and fair view in accordance with the stated financial reporting framework and the various acts and statutes establishing the SGCs. A qualified opinion means that the auditor is unable to obtain sufficient appropriate audit evidence on which

Table 1. CEO managerial leadership competency framework.

\begin{tabular}{ll}
\hline 1) Visionary & 2) Modesty \\
3) Inspirational & 4) Face-saver \\
5) Self-sacrificial & 6) Bureaucratic \\
7) Empathy & 8) Professional practice \\
9) Integrity & 10) Business acumen \\
11) Decisive & 12) Financial management \\
13) Team oriented & 14) Human resources management \\
15) Easily understood & 16) Technology \\
17) Malevolent & 18) Communications and marketing \\
19) Administratively competent & 20) Commercial skills \\
21) Participative & 22) Community relations \\
23) Autocratic
\end{tabular}

Source: Dickinson Dunstan Turinawe, 2020. 
to base the opinion, but the auditor concludes that the possible effects on the financial statements of undetected misstatements could be material but not pervasive. A disclaimer of opinion means that the auditor is unable to obtain sufficient appropriate audit evidence on which to base the opinion, and the auditor concludes that the possible effects on the financial statements of undetected misstatements are both material and pervasive. An adverse opinion is when the auditor, having obtained sufficient appropriate evidence, concludes that misstatements are both material and pervasive to the financial statements.

\subsection{Instrument Validity and Reliability}

\subsubsection{Validity}

A panel of 10 senior academic researchers of Makerere University Business School (MUBS) were used to rate the validity of the questionnaire for the CEO leadership competencies. The instrument validity was evaluated in terms of content validity (whether measures reflect the relevant content domain for the variables) and construct validity (whether measures actually reflect the behaviours of the research variables) [47] [48] [49].

\subsubsection{Reliability}

Reliability of the questionnaire was assessed basing on responses from 30 purposively selected members of selected SGCs using correlation analysis. Reliability refers to the degree to which the instrument produces consistent findings over time which is determined by the internal consistency of items that are used to measure variables [48]. In this research, the responses from 30 purposively selected members of SGCs were analyzed [50]. For this research, alpha coefficient of 0.987 was considered excellent.

\subsection{Population and Sampling Method}

\subsubsection{Population Size}

The categorization under this research consisted of the development of two cohorts of SGCs-performing and non-performing. The basic period considered was financial years 2014/2015 and 2015/2016. The organization with unqualified opinion in the Auditor General's reported for the 2 consecutive years was put in the cohort for performing SGCs while those with, any other opinion in any or both years, were put in the cohort for non-performing SGCs. The reason for this categorization was that failure to comply with Auditor General's requirements means degraded performance on the part of the SGC, in terms of service delivery [2]. Using this approach, the performing cohort with 57 SGCs while that non-performing consisted of 36 SGCs. The two cohorts constituted the study population of 93 SGCs.

\subsubsection{Sampling Method}

The sampling process started with determination of the unit of analysis. The importance of specifying the unit of analysis in research is well articulated in the existing literature [51] [52] [53]. This has relevance when determining the ap- 
propriate unit of inquiry and construct measures [54]. For the present research, the unit of analysis was the CEO. On the other hand, the units of inquiry for CEO LCs included top and senior managers [55] [56] [57] [58] of the sampled organizations.

The individual perceptions of top and senior managers selected from the SGCs were aggregated to constitute the mean of individual scores [59]. These units of inquiry offered data about the CEO LCs. This view is supported by [60], who found a high correlation between data gathered from managers and from employees at different levels in the organizational hierarchy.

\subsubsection{Sample Size}

A total of 93 SGCs were identified as the population. These organizations included corporations, authorities and commissions as SGCs. Based on the Auditor General's report, the SGCs were categorized into performing and non-performing cohorts.

A sample of 30 SGCs from each cohort was randomly selected. The inquiry samples constituted three TMT members and two senior managers from each of the 30 organizations in each cohort. This met the recommendation of a minimum sample for statistical analysis [50] [61] and gave a sample size of 150 respondents for each of the two cohorts giving rise to a total of 300 respondents.

To control response matching, a sampling strategy-advocated by [62]—where the same kind of top and middle managers in all selected SGCs was used. The respondents considered were TMTs and senior managers of the SGCs.

\subsection{Data Collection}

The instrument for measuring CEO LCs was given to Top Management Team members (TMTs) and senior managers. A total of 300 questionnaires were distributed to respondents through contact persons in the SGCs based on three TMT and two senior managers criterion, from each target organization. The response was 240, out which five were rejected because of being incomplete, which left 235 questionnaires suitable for analysis. This constituted a response rate of $78 \%$. [63] defined response rate as the percentage of respondents who are actually return the completed instruments with the required data and those who agree to participate. There is no agreed standard of minimum acceptable response rate although some researchers say it could be as low as 35\% [64]. Others argued that it could vary from $30 \%$ to $75 \%$ [65]. Based on these observations, the response rate was considered appropriate for this research.

For organization performance, the SGCs were categorized into two cohorts of SGCs-performing and non-performing. The basic period considered was financial years 2014/2015 and 2015/2016. The organization with unqualified opinion in the Auditor General's reported that 2 years was put in the cohort for performing SGCs while those with any other opinion were put in the cohort for nonperforming SGCs. The reason for this categorization was that failure to comply with Auditor General's requirements means degraded performance on the part of the 
SGC, in terms of service delivery [2]. This analysis was applied to the sample of 30 organizations in each cohort.

\section{Data Analysis}

A statistical analysis was applied to determine the significant CEO leadership competency differences between performing and non-performing corporations. Since the CEO is the unit of analysis, the responses from the units of inquiry were aggregated and the aggregated data was used in the analysis. Using exploratory factor analysis, the critical and threshold dimensions of CEO leadership competencies were identified. The results of the analysis informed the status of the propositions and the development of a leadership competency framework for CEOs of SGCs. Quantitative data analysis was carried out with the use of IBM SPSS software. The analysis results were useful in making statistical explanations and inferences [48] about CEO leadership competencies.

To measure agreement on CEO leadership competencies by units of inquiry, an agreement level of $75 \%$ was used as the minimum level to accept or reject a CEO leadership competency [66]. A competency standard deviation of 1.00 or less was considered to indicate agreement between the units of inquiry on the rating of that competency item [67]. The CEO competencies that passed this criterion were selected for clustering using EFA.

The EFA was used to explore the CEO leadership competency clusters in each of the categories: the performing and non-performing categories of the SGCs. The PCA run with Varimax enabled identification of clusters of leadership competencies that were clustered closely together. In relation to the research objectives, the mode analysis of the data is as indicated in Table 2 under the heading technique or statistical tests.

\subsection{CEO Leadership Competency Identification}

The quantitative data was collected using the CEO leadership competencies instrument and coded. The process of identification of CEO leadership competencies

Table 2. Test techniques.

\begin{tabular}{ccc}
\hline No. & Objective & $\begin{array}{c}\text { Technique or } \\
\text { statistical tests }\end{array}$ \\
\hline 1 & To compare the demographic data of respondents. & Pearson chi-square test \\
2 & $\begin{array}{c}\text { To examine the agreement amongst } \\
\text { respondents on CEO leadership competencies. }\end{array}$ & Descriptive analysis \\
& $\begin{array}{c}\text { To establish the differences between CEO } \\
\text { leadership competencies in the different cohorts. }\end{array}$ & T-test for pairs of cohorts \\
& To establish the important CEO & T-test for pairs of cohorts \\
4 & leadership competencies. & Exploratory factor analysis \\
& Determination of CEO leadership & (EFA)
\end{tabular}

Source: Dickinson Dunstan Turinawe, 2020. 
involved establishing the descriptive statistics of sampled SGCs, the threshold and differentiating competencies. This was concluded with dimension reduction using EFA to facilitate triangulation of the quantitative and qualitative data during the synthesis and integration stage. The main purpose of using EFA was to reduce the multi-collinearity within the CEO leadership instrument using the correlation matrix determinant as a reference point.

To have distinct items, the correlation matrix determinant had to be greater than 0.00001 , the KMO measure of sample size adequacy had to be more than 0.7 and Bartlett's test of sphericity had to significant with $p<0.05$ [68]. This was achieved through an iterative process of elimination of highly correlated items in the correlation matrix until the acceptable value of the determinant was achieved. The t-test analysis of performing and non-performing SGCs identified two clusters of CEO leadership competencies: differentiating and threshold.

\subsubsection{Descriptive Statistics of Sampled SGCs}

The descriptive statistics of the CEO leadership competencies as rated by top managers and senior managers returned 131 competencies with standard deviation of $<1$, indicating a high degree of agreement among the respondents [67]. This showed that there was general agreement amongst the respondents with regard to the rating of their managers in as far as the competency items are concerned. The descriptive statistics were aggregated to reflect the unit of analysis-the $\mathrm{CEO}$ of the SGC. The results showed that a total of $49 \mathrm{CEOs}$ were assessed by the respondents over the 131 items. The ratings of the CEO leadership competencies were rated at an average minimum of 2.40 (disagree) to an average maximum of 5.00 (strongly agree).

\subsubsection{Differentiating CEO Leadership Competencies}

The independent sample $t$-test indicated that there were 36 that showed significant difference in the CEO leadership competencies between the performing and non-performing cohorts. These competencies had an average mean rating above 3.8 with a standard deviation of $<1$ and significant $p$-value of $p<0.05$. The rating falls in the range of "agree" to "strongly agree". The competencies were interpreted to be differentiating in the performance of CEOs of the SGCs in the two cohorts [69]. The average mean ratings of CEOs of SGCs of performing cohorts were higher for all the competencies except for two- "ability to stimulate unrest" (reversed) and "having an understanding of the law, the legislative process and governance".

\subsubsection{The EFA of Differentiating Leadership Competencies}

The EFA process reduced the differentiating competencies from 36 to 12, which were clustered into two components, and were assessed to be conceptual and administrative leadership competencies. The reduction was achieved through an iterative process that led statistics of KMO coefficient of sample adequacy of 0.767 , significant Bartlett's test of sphericity $\left(\chi^{2}=465.489, \mathrm{df}=66\right.$ and $\left.\mathrm{p}<0.000\right)$ and a correlation matrix determinant of $2.074 \mathrm{E}-5>0.00001$. The composite 
components accounted for $70.6 \%$ of the variance in CEO leadership competencies.

\subsubsection{Threshold CEO Leadership Competencies}

The independent samples $t$-test returned a total of 95 CEO leadership competencies that showed a non-significant difference between the performing and nonperforming cohorts. All the competencies were rated a mean average above 4 meaning that these competencies fell in the range "agree" and "strongly agree". These competencies were considered to be the threshold LCs for a CEO of an SGC. They were termed threshold leadership competencies because they constituted the basis knowledge, skills, traits, motives and social roles that are essential to perform the job of a CEO of an SGC [70]. This set of competencies was interpreted to be the basic Leadership competencies that a CEO of an SGC should have.

\subsubsection{EFA for Threshold CEO Leadership Competencies}

The EFA revealed that the threshold competencies could be reduced from 95 CEO leadership competencies to 17 distinct ones, which constituted four components with statistics of KMO sampling adequacy coefficient of 0.804 , a significant Bartlett's test $\left(\chi^{2}=474.176, \mathrm{df}=136\right.$ and $\left.\mathrm{p}=0.000\right)$ and Correlation Matrix determinant of $1.091 \mathrm{E}-5>0.00001$. The four composite components accounted for $68.8 \%$ of the variance in CEO LCs they were classified as participative, team building, emotional Intelligence and consciousness.

\section{Results and Discussions}

\subsection{Proposition 1: There Is Agreement amongst Respondents on the Need for Managerial and Leadership Competencies at CEO Level}

The descriptive statistics of aggregated responses of TMT and Senior Managers on CEO LCs showed rating above 4 on a 5-likert scale. A total of 131 competencies were rated: 46 were leadership while 75 were managerial.

The high ratings of both categories of competencies are in agreement with [28] who argues that Leadership and management are complementary for achievement of organizational goals. This argument is supported by scholars like [41] and [21] who argue that the two competencies can coexist. Moreover, [40] noted that separating leadership and management competencies may be intuitivel appealing, but this does not represent the realities of executives in senior positions; in this research the CEOs of SGCs. [71] and [72] observed that a CEO must have many skills, knowledge, behavior, abilities and attitudes in order to control the setting within the company. Leaders and managers play similar roles [73] and some individuals who have the capacity to fulfil the roles of both a leader and a manager [39]. Also many other scholars have argued that the balance between the manager's roles and the leader's roles, is vital for the best organization outcomes [73] [74]. With this observation, the results show that Proposition 2 is true. 


\subsection{Proposition 2: There Is a Cluster of CEO Threshold Managerial Leadership Competencies}

The independent samples $t$-test returned a total of 95 CEO leadership competencies that showed a non-significant difference between the performing and nonperforming cohorts. All the competencies were rated a mean average above 4 meaning that these competencies fell in the range "agree" and "strongly agree". These competencies were considered to be the threshold LCs for a CEO of an SGC. They were termed threshold leadership competencies because they constituted the basis knowledge, skills, traits, motives and social roles that are essential to perform the job of a CEO of an SGC [70]. This set of competencies was interpreted to be the basic Leadership competencies that a CEO of an SGC should have. The threshold LCs had 67 Managerial competencies and 28 leadership competencies. These results supported proposition 3 as true.

\subsection{Proposition 3: There Is a Cluster of Differentiating Managerial Leadership Competencies}

The independent sample $t$-test indicated that there were 36 ) of which 12 were leadership oriented while 24 were managerial-oriented, that showed significant difference in the CEO leadership competencies between the performing and nonperforming cohorts. These competencies had an average mean rating above 3.8 with a standard deviation of $<1$ and significant $\mathrm{p}$-value of $\mathrm{p} \leq 0.05$. The ratings fells in the range of "agree" to "strongly agree". The competencies were interpreted to be differentiating in the performance of CEOs of the SGCs in the two cohorts [69]. These results supported Proposition 4 as being true.

\subsection{Proposition 4: The Differentiating Managerial Leadership Competencies Can Be Categorized into Principle Components}

The EFA process reduced the differentiating competencies from 36 to 12 , which were clustered into two components, and were assessed to be conceptual and administrative leadership competencies. The reduction was achieved through an iterative process that led to statistics of KMO coefficient of sample adequacy of 0.767, significant Bartlett's test of sphericity $\left(\chi^{2}=465.489\right.$, df $=66$ and $\left.\mathrm{p}<0.000\right)$ and a correlation matrix determinant of $2.074 \mathrm{E}-5>0.00001$. The composite components accounted for $70.6 \%$ of the variance in CEO leadership competencies as shown in Table 3.

As shown in Table 4, EFA dimension reduction is consistent with the general analysis of Differentiating CEO LCs. Out of 12 competencies 8 were managerial while 4 were leadership oriented. Ten were categorized as conceptual and two administrative components of the differentiating CEO competencies.

\subsection{Proposition 5: The Threshold Managerial Leadership Competencies Can Be Categorized into Principle Components}

The EFA revealed that the threshold competencies could be reduced from 95 CEO leadership competencies to 17 distinct ones, which constituted four 
Table 3. Differentiating CEO leadership competencies.

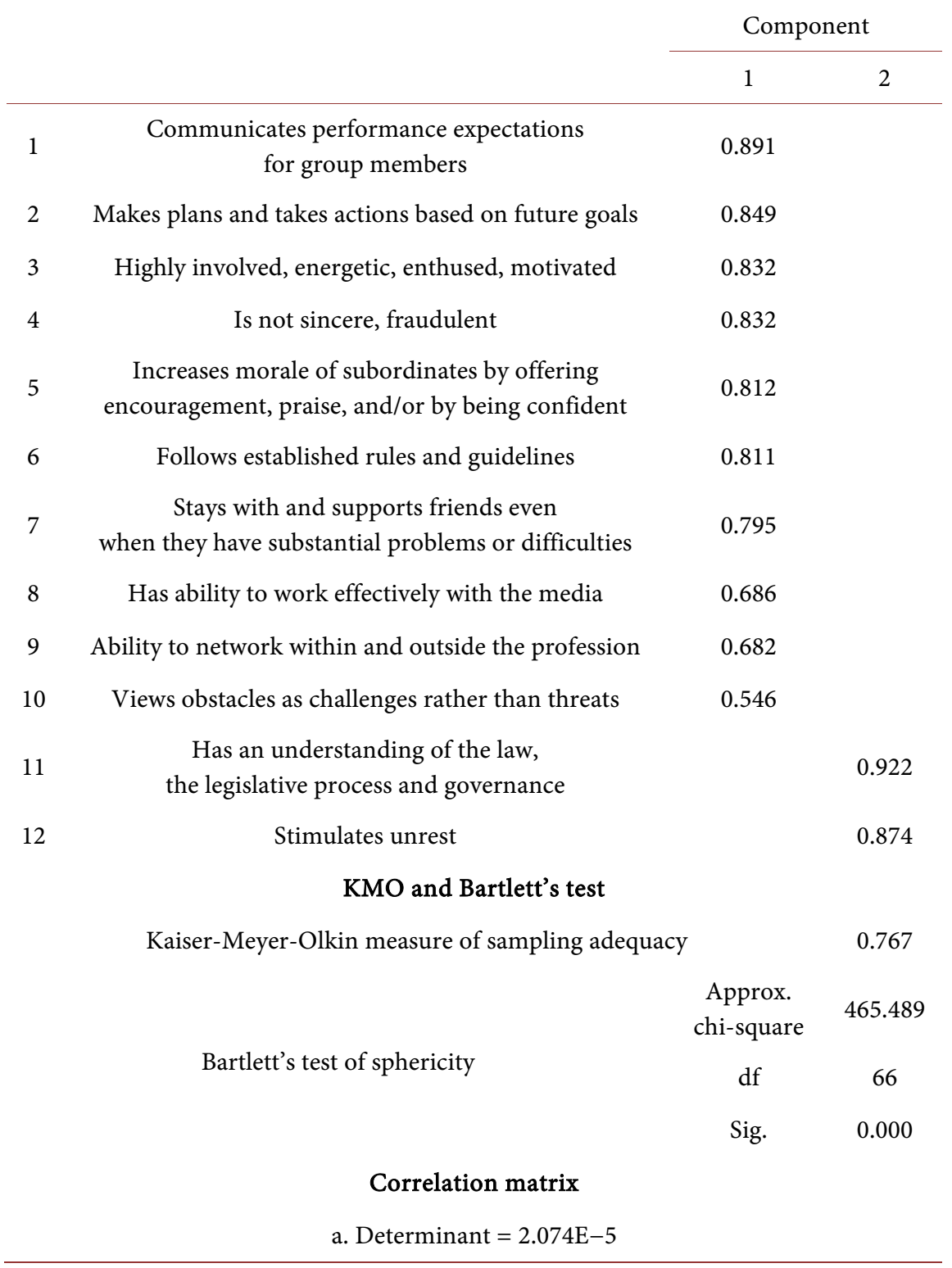

Source: Dickinson Dunstan Turinawe, 2020.

Table 4. Competency categories in differentiating CEO LCs.

\begin{tabular}{cccc}
\hline Component & $\begin{array}{c}\text { No. of } \\
\text { competencies }\end{array}$ & $\begin{array}{c}\text { Managerial } \\
\text { competencies }\end{array}$ & $\begin{array}{c}\text { Leadership } \\
\text { competencies }\end{array}$ \\
\hline Conceptual & 10 & 6 & 4 \\
Administrative & 2 & 2 & 0 \\
\hline
\end{tabular}

Source: Dickinson Dunstan Turinawe, 2020.

components with statistics of KMO sampling adequacy coefficient of 0.804, a significant Bartlett's test $\left(\chi^{2}=474.176, \mathrm{df}=136\right.$ and $\left.\mathrm{p}=0.000\right)$ and Correlation Matrix determinant of $1.091 \mathrm{E}-5>0.00001$ as indicated in Table 5 on threshold 
Table 5. Threshold leadership competencies.

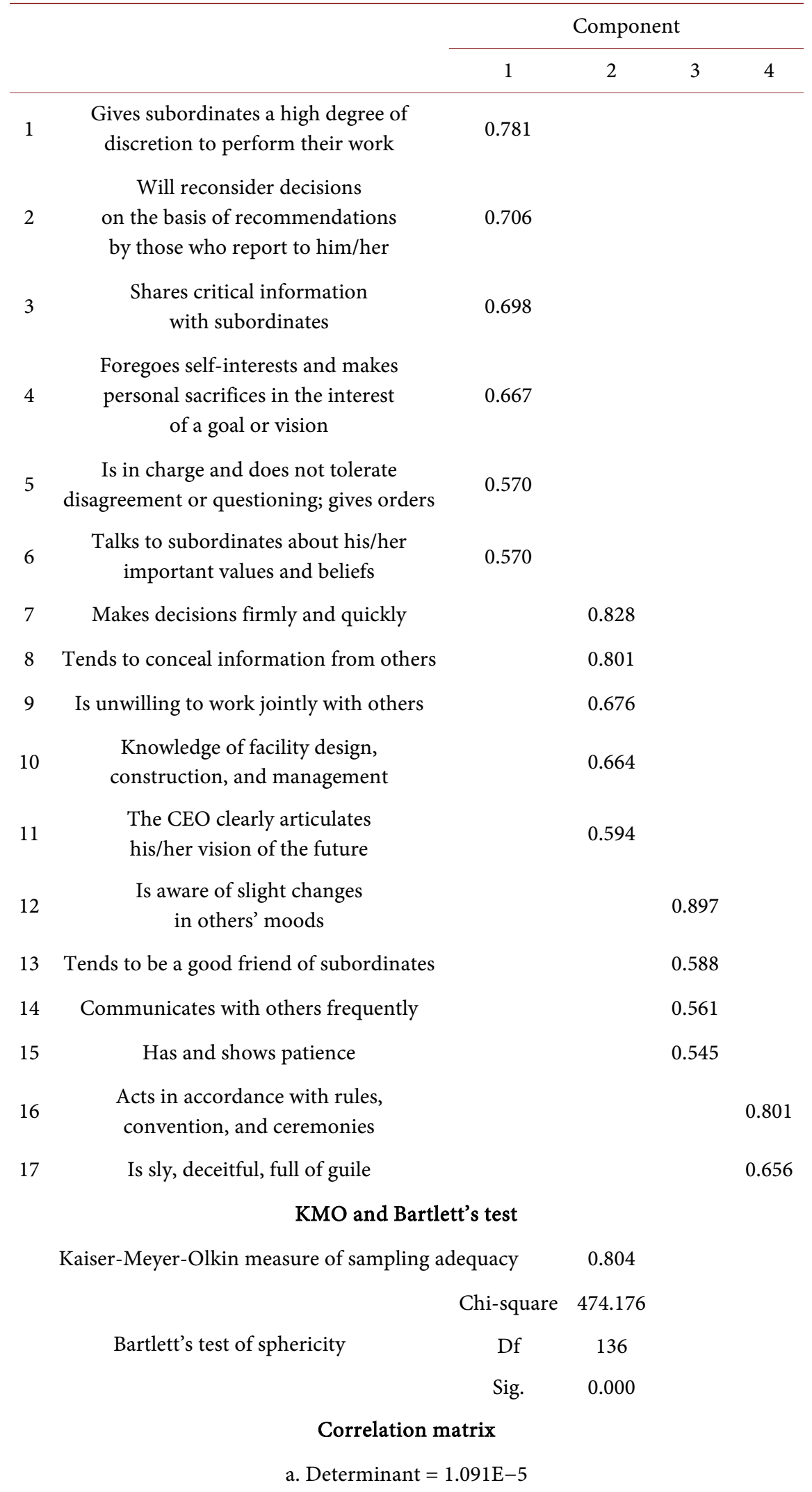

Source: Dickinson Dunstan Turinawe, 2020. 
Table 6. Competency categories in threshold CEO LCs.

\begin{tabular}{cccc}
\hline Component & $\begin{array}{c}\text { No. of } \\
\text { Competencies }\end{array}$ & $\begin{array}{c}\text { Managerial } \\
\text { Competencies }\end{array}$ & $\begin{array}{c}\text { Leadership } \\
\text { Competencies }\end{array}$ \\
\hline Participative & 6 & 3 & 3 \\
Team Building & 5 & 3 & 2 \\
Emotional Intelligence & 4 & 4 & 0 \\
Conscientiousness & 2 & 2 & 0 \\
\hline
\end{tabular}

Source: Dickinson Dunstan Turinawe, 2020.

leadership competencies. The four composite components accounted for $68.8 \%$ of the variance in CEO LCs. They were classified as participative, team building, emotional Intelligence and consciousness.

The dimension reduction using EFA returned four components as illustrated in Table 6, show that the threshold CEO competencies have four components -participative, team building, emotional intelligence and Conscientiousness. It is noted that just as in the case of the general analysis of the CEO Threshold LCs, out of the 17 dimensionally reduced number of LCs 12 were managerial while five were leadership. This observation is supported by [22] who contends that in today's dynamic environment, organizations need both leaders and managers. It also tallies with [75] who likens the difference between leadership and management to a continuum ranging from innovation and change on one end to stability and order at the other.

Moreover, [76] found out that most truly successful individuals in key directive roles in organizations develop a capability to perform both sets of functional responsibilities well. This is consistent with many research finding as was the case of Differentiating Competencies [75]. The results support proposition 6 as true.

\section{Conclusions and Implications}

The main argument in extant literature has been that leadership and management are different and therefore, their appropriate competencies are different. To identify the characteristics of a leadership competency framework for CEOs of SGCs in Uganda, a cross-sectional quantitative study was conducted.

\subsection{Research Findings}

The research uncovered three major findings. The first finding was differentiating and threshold leadership competencies of CEOs of SGCs in Uganda. The research showed that there were 12 LCs that differentiated the performance of the CEOs of SGCs. The study identified 17 threshold leadership competencies.

The second finding was that at the level of a CEO, both leadership and managerial competencies were integrated for effective leadership. The research showed that managerial competencies were essential for both the differentiating and thre- 
shold leadership competencies for a CEO of an SGC in Uganda. This provides credence to the argument that at the level of a CEO, managerial and leadership competencies are integrated. The import on this finding is that a CEO of an SGC in Uganda will be an outstanding performer when he/she plays the role of leader-manager.

\subsection{Significance of Research Findings}

The research findings brought out three significant issues that inform the running of SGCs.

1) The research findings will constitute the reference for identification of the competencies needed by CEOs of SGCs in the recruitment process. For practical purposes the competency Profile established by this research will facilitate recruitment of CEOs for SGCs in Sub-Saharan region. The human resource recruitment process will be enabled with the identification of LCs by looking for behaviours that indicate the latent leadership competencies exhibited by potential effective CEOs and TMT in SGCs. The differentiating competencies are considered to be critical for superior performance. Their appropriate indicators should be given higher weights when designing the appraisal instruments.

2) From the theoretical perspective, the debate on the integration of leadership and management theories will be enhanced by the findings. For top management, role playing of a leader-manager is recommended for effective organizational performance. At CEO level, the two categories of leadership and managerial competencies are complementary, whether differentiating or threshold. This observation fosters the relevancy of the concept of managerial leadership competencies at CEO level.

3) This research revealed that at the level of a Chief Executive Officer, the relevant approach to leadership competencies is the concept of managerial leadership competencies which recognizes the complementarity of leadership and managerial competencies as the appropriate leadership competency profile. At this level, both sets of competencies have significant impact on organizational outcomes.

\section{Conflicts of Interest}

The author declares no conflicts of interest.

\section{References}

[1] Kauza, J. (2008) Public Enterprises: Unresolved Challenges and New Opportunities in the Question of the Public Enterprise and Africa's Development Challenge: A Governance and Leadership Perspective. United Nations, New York.

[2] Mafabi, S., Munene, J.C. and Ntayi, J.M. (2012) Knowledge Management and Organisational Resilience: Organisational Innovation as a Mediator in Uganda Parastatals. Journal of Strategy and Management, 5, 57-80.

https://doi.org/10.1108/17554251211200455

[3] Rondinelli, A.D. (2008) Public Enterprises: Unresolved Challenges and New Op- 
portunities, Can Public Enterprises Contribute to Development? A Critical Assessment and Alternatives for Management Improvement. United Nations, New York.

[4] World Bank (2010) Doing Business Reforming through Difficult Times. The International Bank for Reconstruction and Development/World Bank, Washington DC.

[5] McGrath, R.G. and MacMillan, I. (2000) Entrepreneurial Mindset: Strategies for Continuously Creating Opportunity in an Age of Uncertainty. Harvard Business School Press Books, Harvard.

[6] Teece, J.D., Pisano, G. and Shuen, A. (1997) Dynamic Capabilities and Strategic Management. Strategic Management Journal, 18, 509-533.

https://doi.org/10.1002/(SICI)1097-0266(199708)18:7<509::AID-SMJ882>3.0.CO;2-Z

[7] Jing, F.F. and Avery, G.C. (2008) Missing Links in Understanding the Relationship between Leadership and Organisational Performance. International Business \& Economic Research Journal, 7, 67-78.

[8] Ramayah, T., Samat, N. and Lo, M.C. (2011) Market Orientation, Service Quality, and Organizational Performance in Service Organizations in Malaysia. Asia-Pacific Journal of Business Administration, 3, 8-27. https://doi.org/10.1108/17574321111116379

[9] Richard, P.J., Devinney, T.M., Yip, G.S., et al. (2009) Measuring Organizational Performance: Towards Methodological Best Practice. Journal of Management, 35, 718-804. https://doi.org/10.1177/0149206308330560

[10] Kirby, J. (2005) Toward a Theory of High Performance. Harvard Business Review, July-August, 30-39.

[11] Kuei, C.H., Madu, C.N. and Lin, C. (2001) The Relationship between Supply Chain Quality Management Practices and Organisational Performance. International Journal of Quality \& Reliability Management, 18, 864-872.

https://doi.org/10.1108/EUM0000000006031

[12] Terziovski, M. and Samson, D. (1999) The Link between Total Quality Management and Organizational Performance. International Journal of Quality \& Reliability Management, 16, 226-237. https://doi.org/10.1108/02656719910223728

[13] Cameron, A. (1986) A Study of Organisational Effectiveness and Its Predictors. Management Science, 32, 87-112. https://doi.org/10.1287/mnsc.32.1.87

[14] Goodman, P.S. and Pennings, M. (1977) New Perspectives on Orgatzizational Effectivetzess. Jossey-Bass, San Francisco.

[15] Steers, M.R. (1975) Problems in the Measurement of Organisational Effectiveness. Administrative Science Quarterly, 20, 546-558. https://doi.org/10.2307/2392022

[16] Hansen, G. and Wernerfelt, B. (1989) Determinants of Firm Performance: The Relative Importance of Economic and Organisational Factors. Strategic Management Journal, 10, 399-411. https://doi.org/10.1002/smj.4250100502

[17] Muirimi, L. (2017) An Assessment of Strategic Corporate Social Responsibility (CSR) as a Competitive Tool in Zimbabwe's Mining Sector for the Period 2008-2012.

[18] Agahtani, A. (2014) Are Leadership and Management Different? A Review. Journal of Management Policies and Practices, 2, 71-82.

https://doi.org/10.15640/jmpp.v2n3a4

[19] Bass, B.M. and Avolio, B.J. (1995) MLQ Multifactor Leadership Questionaire. Technical Report, Mind Garden, Redwood City. https://doi.org/10.1037/t03624-000

[20] Yukl, G.A. (2010) Leadership in Organizations. 7th Edition, Pearson Hall, Upper Saddle River.

[21] Ricketts, K.G. (2009) Leadership vs Management. http://www2.ca.uky.edu/agcomm/pubs/elk1/elk1103/elk1103.pdf 
[22] Kotterman, J. (2006) Leadership vs Management: What Is the Difference? Journal of quality and Participation, 29, 13-17.

[23] Zeleznik, A. (1977) Managers and Leaders: Are They Different? Harvard Business Review, 55, 67-78.

[24] Bennis, W. (1959) Leadership Theory and Administrative Behaviour: The Problems of Authority. Administrative Science Quarterly, 8, 125-165.

[25] Bennis, W.G. and Nanus, B. (1985) Leaders: The Strategies of Taking Charge. Harper and Row, New York.

[26] Kumalo, M. and Scheepers, C.B. (2020) Leadership of Change in South Africa Public Sector Turnarounds. Journal of Organizational Change Management, 34, 137-157. https://doi.org/10.1108/JOCM-04-2017-0142

[27] Fernandez-Araoz, C., Roscoe, A. and Aramaki, K. (2017) Turning a Potential into Success; The Missing Link in Leadership Development. Harvard Business Review, 95, 86-93.

[28] Kotter, J. (2001) What Leaders Really Do? Harvard Business Review, 79, 85-96.

[29] Bass, B.M. (1983) Organizational Decision Making. Irwin, Homewood.

[30] Kim, H. (2020) Comparison of Strategic Leadership: Steve Jobs and Tim Cook. Business and Management Studies, 6, 17-25. https://doi.org/10.11114/bms.v6i3.5010

[31] Schein, E.H. (1978) Career Dynamics: Matching Individual and Organizational Needs. Addison Wesley, Reading.

[32] Boyatzis, R.E. (1982) The Competent Manager. John Wiley and Sons, New York.

[33] Covey, S. (1991) Principle-Centered Leadership. Simon \& Schuster, Inc., New York.

[34] Spencer, J.L.M. and Spencer, S.M. (1993) Competence at Work: Models of Superior Performance. Wiley, New York.

[35] Maxwell, J.C. (1995) Developing the Leaders around You: How to Help Others Reach Their Full Potential. Thomas Nelson, Inc, Nashville.

[36] Marquardt, M.J. and Berger, N.O. (2000) Global Leaders for the Twenty-First Century. State University of New York Press, Albany.

[37] Quinn, R. (1996) Deep Change: Discovering the Leader within. Jossey-Bass Publishers, San Francisco.

[38] Bartram, D. (2011) The SHL Corporate leadership Model. 2nd Edition, SHL Group Ltd., Thames Ditton.

[39] Crosthwaite, C. (2010) Managerial Leadership Competencies of Heads of Departments: A Case Study of Higher Educational Institutions.

[40] House, R.J., Dorfman, P.W., Javian, M., Hanges, P.J. and de Luque, M.S. (2013) Strategic Leadership across Cultures: GLOBE Study of CEO Leadership Behavior and Effectiveness in 24 Countries. Sage Publications, Thousand Oaks, 383. https://doi.org/10.4135/9781506374581

[41] Bargau, M. (2015) Leadership vs Management. Romanian Economic and Business Review, 10, 182-183.

[42] Mtshali, Z., Proches, C.N. and Green, P. (2018) Challenges That Hinder Effective Implementation a Talent Management System: A Case of a Public Electricity Company in South Africa. International Journal of Applied Engineering Research, 13, 1286-1293.

[43] Amedu, S. and Delewicz, V. (2018) The Relationship between CEO Personal Power, CEO Competencies and Company Performance. Journal of General Management, 43, 188-198. https://doi.org/10.1177/0306307018762699 
[44] Hurd, A.R. and McLean, D.D. (2004) Analysis of Perceived Competencies of CEOs in Public Parks and Recreation Agencies. Managing Leisure, 9, 96-110. https://doi.org/10.1080/13606710410001709626

[45] Bonica, M.J., Mayhugh, C. and Mellot, M.D. (2020) Learned the Hard Way: A Model of Executive Leadership Competencies. Global Journal of Management and Business Research, 20.

[46] Cooper, D.R. and Schindler, P.S. (2006) Business Research Methods. 9th Edition, McGraw-Hill, New York.

[47] Sarantonkos, S. (1997) Social Research. Palgrave, New York.

[48] Saunders, M., Lewis, P. and Thornhill, A. (2007) Saunders, Research Methods for Business Students. 4th Edition, Prentice-Hall, London.

[49] Munyengabe, S., He, H. and Yiyi, Z. (2018) Information Communication Technology Policy and Public Primary Schools' Efficiency in Rwanda. South African Journal of Education, 38, 1-10. https://doi.org/10.15700/saje.v38n1a1445

[50] Sekaran, U. (2003) Research Methods for Business: A Skill-Building Approach. 4th Edition, John Wiley \& Sons, Singapore.

[51] Malhotra, M.K. and Grover, V. (1998) An Assessment of Survey Research in POM: From Construct to Theory. Journal of Operations Management, 16, 407-425. https://doi.org/10.1016/S0272-6963(98)00021-7

[52] Miller, V.A., Reynolds, W.W., Itternbach, R.F., Luce, M.F., Beauchamp, T.L. and Nelson, R.M. (2009) Challenges in Measuring a New Construct: Perception of Voluntariness for Research and Treatment Decision Making. Journal of Empirical Research Human Research Ethics, 4, 21-31. https://doi.org/10.1525/jer.2009.4.3.21

[53] Neilsen, B. (2014) Construct Measurement in Management Research: The Importance of Match between Levels of Theory and Measurement. Journal of Business Research, 67, 403-406. https://doi.org/10.1016/j.jbusres.2012.12.020

[54] Maurel, C. (2009) Determinants of Export Performance in French Wines. International Journal of Wine Business Research, 21, 118-142. https://doi.org/10.1108/17511060910967971

[55] Baumgarth, C. (2010) Living the Brand: Brand Orientation in the Business-to-Business Sector. European Journal of Marketing, 45, 653-671. https://doi.org/10.1108/03090561011032315

[56] Kroop, F., Lindsay, N.J. and Shoham, A. (2006) Entrepreneurial, Market, and Learning Orientations and International Business Venture Performance in South African Firms. International Marketing Review, 23, 504-523. https://doi.org/10.1108/02651330610703427

[57] Melén, S. and Nordman, E.R. (2009) The International Modes of Born Global Firms: A Longitudinal Study. European Management Journal, 27, 243-254. https://doi.org/10.1016/j.emj.2008.11.004

[58] Spyropoulou, S., Skarmeas, D. and Katsikeas, C.S. (2011) An Examination of Branding Advantage in Export Ventures. European Journal of Marketing, 45, 910-935. https://doi.org/10.1108/03090561111119967

[59] Dolma, S. (2010) The Central Role of the Unit of Analysis Concept in Research Design. Journal of the School of Business Administration, 39, 169-174.

[60] Young, S.I. (2009) The Relationship between Organizational Fitness and Business Performance: Specific Evidence for SMEs. PhD Thesis, Aukland University of Technology, Auckland.

[61] Mohamad, W.I.A.W. and Sulong, Z. (2010) Corporate Governance Mechanisms and 
Extent of Closure: Evidence from Listed Companies in Malaysia. International Business Research, 3, 216. https://doi.org/10.5539/ibr.v3n4p216

[62] Baer, M. and Frese, M. (2003) Innovation Is Not Enough; Climates for Initiative and Psychological Safety, Process Innovationism, and Firm Performance. Journal of Organizational Behaviour, 24, 45-68. https://doi.org/10.1002/job.179

[63] Burnes, N. and Grove, S.K. (2011) Understanding Nursing Research-Building an Evidence-Based Practice. 5th Edition, Elsevier Saunders, Maryland Heights.

[64] Nulty, D. (2008) The Adequacy of Response Rates to Online and Paper Surveys: What Can Be Done? Assessment and Evaluation in Higher Education, 33, 301-314. https://doi.org/10.1080/02602930701293231

[65] Bowling, A. (2009) Research Methods in health: Investing Health and Health Services. Third Edition, Open University Press, Maidenhead.

[66] Edgren, G. (2006) Developing a Competence-Based Core Curriculum in Biomedical Laboratory Science: A Delphi Study. Medical Teacher, 28, 409-417. https://doi.org/10.1080/01421590600711146

[67] Daud, R., Ismail, M. and Omar, Z. (2010) Identification of Competencies for Malaysian Occupation Safety and Health Professionals. Industrial Health, 48, 824-834. https://doi.org/10.2486/indhealth.MS1115

[68] Field, A. (2013) Discovering Statistics Using IBM SPSS Statistics. Oriental Press, Dubai.

[69] Lakshminarayanan, S., Pai, Y.P. and Ramaprasad, B.S. (2016) Managerial Competencies, Self Efficacy, and Job Performance: A Path Analytic Approach. Prabandan: Indian Journal of Management, 9, 7-22. https://doi.org/10.17010/pijom/2016/v9i10/103068

[70] Cech, P. and Chadt, K. (2015) Project Manager and His/Her Competencies. International Conference Knowledge-Based Organization, 21, 165-169. https://doi.org/10.1515/kbo-2015-0027

[71] Trivellas, P. and Reklitis, P. (2014) Leadership Competencies Profile and Managerial Effectiveness in Greece. Pocedia Economics and Finance, 9, 380-390. https://doi.org/10.1016/S2212-5671(14)00039-2

[72] Powers, R. (2015) Leadership Competency Models; Contemporary Issues in Leadership, Sabrina Flemming: Ashford University.

[73] Toor, S. (2011) Differentiating Leadership from Management: An Imperical Investigation of Leaders and Managers. Leadership and Management in Engineering, 11, 310-320. https://doi.org/10.1061/(ASCE)LM.1943-5630.0000138

[74] Yukl, G. (1999) An Evaluative Essay on Current Conceptions of Effective Leadership. European Journal of Work and Organizational Psychology, 8, 33-48. https://doi.org/10.1080/135943299398429

[75] Yukl, G. and Lepsinger, R. (2005) Why Integrating Leading and Managing Roles Is Essential for Organizational Effectiveness. Organizational Dynamics, 34, 361-375. https://doi.org/10.1016/j.orgdyn.2005.08.004

[76] Darling, J. and Nurmi, R. (2009) Key Contemporary Paradigms of Management and Leadership: A Linguistic Exploration and Case of Managerial Leadership. European Business Review, 21, 291-214. https://doi.org/10.1108/09555340910956603 